\title{
THE EFFECT OF PHALERIA MACROCARPA ETHNIC FOOD COMPLEMENTARY TO DECREASE BLOOD PRESSURE
}

\author{
Muhammad Fathur Rizal ${ }^{1}$, Joni Haryanto², Eka Mishbahatul Mar'ah Has ${ }^{3}$
}

1,2,3 Faculty of Nursing, Universitas Airlangga

\section{A BSTRACT}

Introduction: Hypertension is one of degenerative disease that is often found in the elderly group. Many studies have been developed to reduce blood pressure, including complementary therapies. One of the complementary therapies is by utilizing Phaleria Macrocarpa. This study was aimed to explain the effect of Phaleria macrocarpa ethnic food complementary to decrease blood pressure of elderly with hypertension.

Methods : Design used in this study was quasy experiment design. The population was the elderly with hypertension in UPT PSTW Blitar (in Blitar and Tulungagung). Total sampel was 40 respondens, taken according to inclusion criteria. The independent variabel was Phaleria macrocarpa ethnic food complementary. The dependent variabel was blood pressure. Data were collected using measurement blood pressure and made ethnic food complementary with Standart Operational Procedure. Data were analzed using paired t-test and ANOVA with level of significance of $\leq 0,05$.

Results : The Results showed that there were effect of giving intervention by ethnic food complementary with phaleria macrocarpa fruit, leaf, or mixed (fruit and leaf) to decrease blood pressure (systolic, diastolic, and MAP).

Conclusion: This intervention can be used as a complementary therapy herbal to decrease high blood pressure.

\section{ARTICLE INFO}

Recived 4 January 2020

Accepted 15 May 2020

Online 29 May 2020

*Correspondence:

Muhammad Fathur Rizal

*Email:

mutalmanu@gmail.com

Keywords:

Blood Pressure, Elderly, Ethnic

Food Complementary,

Hypertension, Phaleria

Macrocarpa

\section{INTRODUCTION}

Hypertension is a degenerative disease that is often found in the elderly group (Abdullah, 2005). Hypertension has a high prevalence in the elderly, there were $57.6 \%$ elderly with hypertension at the age of 65-74 years (Kemenkes RI, 2013). According to a study which were done by Noorhidayah (2016), out of 104 respondents there were 82 respondents $(78.8 \%)$ who were obedient in taking medication, such as amlodipine or captopril. It turns out that the elderly with hypertension still have a high systolic pressure of $77 \%$.

According to the study of NHANES (2017), those aged 60 years and over who have hypertension in the United States amounted to $63.1 \%$ during 2015-2016. According to the Kemenkes RI (2013), the prevalence of hypertension at the age of 55-64 years is $45.9 \%$, age $65-74$ years is $57.6 \%$, and age $\geq 75$ years reaches $63.8 \%$. The percentage of blood pressure measurements in the elderly in East Java shows that the age group 55-64 years has hypertension as much as $42.5 \%$, age group 65 74 years as much as $54.1 \%$, and age group> 75 years as much as 62\% (Dinkes Provinsi Jatim, 2013). Elderly people who have hypertension in Tulungagung as many as 23,296 people in 2017 , consist of men as many as 8,113 people and women as many as 15,183 people (Dinkes Kabupaten Tulungagung, 2017). Even though the number of elderly people who have hypertension in Tulungagung is not the highest in East Java, the achievements that are served / treated are still not optimal at $54 \%$ (Dinkes Kabupaten Tulungagung, 2017). The theory developed by Miller (2012) explains that functional consequences for the elderly are influenced by changes related to age and risk factors. Elderly people will experience changes in the arteries in the body to be wider and stiffer resulting in reduced recoil capacity of blood vessels. 
Reducing the function of blood vessels causes systolic pressure to increase. Arterial stiffness can also be caused by a buildup of plaque in the arteries (atherosclerosis). Endothelial dysfunction and decreased nitric oxide are associated with increased arterial susceptibility and the incidence of isolated systolic hypertension (ISH) (AHA, 2011 in Yuliana, 2017). Therefore, the participation of all parties, both doctors from various fields of hypertension, government, private and community specialization is needed so that hypertension can be controlled (Kemenkes RI, 2014)

In general, the management of hypertension is divided into pharmacological management and non-pharmacological management. Various studies have been developed to reduce blood pressure, including complementary therapies. One of the complementary therapies is by utilizing Mahkota dewa plant (Phaleria macrocarpa). The researcher was interested in examining the influence of the Phaleria macrocarpa which was packaged in the form of ethnic food. Formerly, the Tulungagugung people used cassava as a staple food before changing into rice. The processed cassava is used as staple food in the form of gaplek or thiwul (Januariani, 2018). While phaleria macrocarpa has been proven and often carried out by the community to reduce blood pressure and not cause complications (Priharninuk, 2017). It is hoped that the administration of the phaleria macrocarpa ethnic food complementary intervention can change negative functional consequences into positive functional consequences.

Therefore, the researcher was interested in examining the effect of phaleria macrocarpa ethnic food complementary intervention on the reduction of blood pressure in elderly people with hypertension in UPT PSTW Blitar (in Blitar and Tulungagung).

\section{MATERIALS AND METHODS}

The research design which used was quasy-experiment. The research subjects were divided into 4 groups, namely intervension group A (50 grams of ethnic food complementary mixed with 15 grams of phaleria macrocarpa's fruit), intervension group B (50 grams of ethnic food complementary mixed with 15 grams of phaleria macrocarpa's leaves ), intervension group C (50 grams of ethnic food complementary mixed with phaleria macrocarpa's leaves as much as 7.5 grams and phaleria macrocarpa's fruit as much as 7.5 grams), and control subjects (ethnic food without mixed with phaleria macrocarpa).

The population in this study were elderly with hypertension at UPT PSTW Blitar (in Blitar and Tulungagung). The sampling was using purposive sampling technique. The sample in the study was 40 respondents. So that each group has 10 respondents.

The time and location of the study was done on December 1-10, 2018 in the UPT PSTW Blitar in Tulungagung and December 11-19, 2018 at the UPT PSTW Blitar in Blitar. The independent variabel is Phaleria macrocarpa ethnic food complementary. The dependent variabel is blood pressure. Data analysis used paired t-test and ANOVA with a significant level of $\leq 0.05$. Data collection prosedur : 1 hour before the study, the researcher conducted a pre-test by measuring blood pressure with a sphygmomanometer in a sitting position; The researcher gave phaleria macrocarpa ethnic food complementary in the intervension group according to their respective groups and ethnic food complementary without the phaleria macrocarpa in the control group; The researcher conducted a post-test by measuring the respondent's blood pressure every 30 minutes for 2 hours after giving an intervention to anticipate the occurrence of hypotension and noting how long the intervention has an effect on reducing blood pressure; As long as the research process takes place, researchers strictly maintain the compliance of the elderly in the study, such as not smoking, consuming coffee and / or fried foods; Final observation is carried out after being given the phaleria macrocarpa ethnic food complementary for 7 consecutive days (8th day). 


\section{RESULTS}

Table 1 Characteristics of respondents based on age groups, stadium of hypertension, activities, and drug consumption.

\begin{tabular}{|c|c|c|c|c|c|c|c|c|c|c|}
\hline \multirow[t]{2}{*}{ No. } & \multicolumn{2}{|c|}{ Characteristics of respondents } & \multicolumn{2}{|c|}{ Intervention A } & \multicolumn{2}{|c|}{ Intervention B } & \multicolumn{2}{|c|}{ Intervention C } & \multicolumn{2}{|c|}{$\begin{array}{l}\text { Control } \\
\text { Group }\end{array}$} \\
\hline & & & $\mathbf{n}$ & $\%$ & $\bar{n}$ & $\%$ & $\bar{n}$ & $\%$ & $\mathbf{n}$ & $\%$ \\
\hline \multirow[t]{7}{*}{1} & Age groups & $61-65$ years & 2 & 20 & 2 & 20 & 2 & 20 & 2 & 20 \\
\hline & & $66-70$ years & 3 & 30 & 2 & 20 & 2 & 20 & 1 & 10 \\
\hline & & $71-75$ years & 2 & 20 & 2 & 20 & 2 & 20 & 3 & 30 \\
\hline & & $76-80$ years & 2 & 20 & 3 & 30 & 2 & 20 & 2 & 20 \\
\hline & & $81-85$ years & 0 & 0 & 1 & 10 & 1 & 10 & 1 & 10 \\
\hline & & $86-90$ years & 1 & 10 & 0 & 0 & 1 & 10 & 1 & 10 \\
\hline & & $\sum$ Respondents & 10 & 100 & 10 & 100 & 10 & 100 & 10 & 100 \\
\hline \multirow[t]{3}{*}{2} & Gender & Male & 1 & 10 & 4 & 40 & 3 & 30 & 3 & 30 \\
\hline & & Female & 9 & 90 & 6 & 60 & 7 & 70 & 7 & 70 \\
\hline & & $\sum$ Respondents & 10 & 100 & 10 & 100 & 10 & 100 & 10 & 100 \\
\hline \multirow[t]{3}{*}{3} & Stadium of & Stadium 1 & 6 & 60 & 5 & 50 & 5 & 50 & 4 & 40 \\
\hline & hypertension & Stadium 2 & 4 & 40 & 5 & 50 & 5 & 50 & 6 & 60 \\
\hline & & $\sum$ Respondents & 10 & 100 & 10 & 100 & 10 & 100 & 10 & 100 \\
\hline \multirow[t]{3}{*}{4.} & Exercise activities & Routine & 4 & 40 & 4 & 40 & 2 & 20 & 4 & 40 \\
\hline & & Not routine & 6 & 60 & 6 & 60 & 8 & 80 & 6 & 60 \\
\hline & & $\sum$ Respondents & 10 & 100 & 10 & 100 & 10 & 100 & 10 & 100 \\
\hline \multirow[t]{4}{*}{5.} & $\begin{array}{l}\text { Hypertension's } \\
\text { druq consumption }\end{array}$ & Routine & 0 & 0 & 0 & 0 & 0 & 0 & 0 & 0 \\
\hline & & Not routine & 8 & 80 & 7 & 70 & 8 & 80 & 8 & 80 \\
\hline & & Not consumption & 2 & 20 & 3 & 30 & 2 & 20 & 2 & 20 \\
\hline & & $\sum$ Respondents & 10 & 100 & 10 & 100 & 10 & 100 & 10 & 100 \\
\hline
\end{tabular}

Table 2. The value of pre and post test, and the results of paired t-test intervention group A

\begin{tabular}{ccccccc}
\hline \multirow{2}{*}{$\begin{array}{c}\text { Respondent } \\
\text { Code }\end{array}$} & \multicolumn{7}{c}{ Intervention group A } \\
\cline { 2 - 7 } & Pre & Post & Pre & Post & Pre & Post \\
\cline { 2 - 7 } & 160 & 150 & 90 & 80 & 113,33 & 103,33 \\
& 180 & 170 & 100 & 90 & 126,67 & 116,67 \\
2 & 150 & 140 & 70 & 70 & 96,667 & 93,333 \\
3 & 170 & 160 & 90 & 80 & 116,67 & 106,67 \\
4 & 160 & 150 & 90 & 80 & 113,33 & 103,33 \\
5 & 170 & 160 & 90 & 80 & 116,67 & 106,67 \\
6 & 150 & 140 & 80 & 70 & 103,33 & 93,333 \\
7 & 160 & 140 & 90 & 70 & 113,33 & 93,333 \\
8 & 160 & 150 & 90 & 80 & 113,33 & 103,33 \\
9 & 170 & 160 & 100 & 90 & 123,33 & 113,33 \\
10 & \multicolumn{7}{c}{$\mathrm{p}=0,000$} & \multicolumn{7}{c}{$\mathrm{p}=0,000$} & & $\mathrm{p}=0,000$ \\
\hline
\end{tabular}

Table 3 The value of pre and post test, and the results of paired t-test intervention group B

\begin{tabular}{|c|c|c|c|c|c|c|}
\hline \multirow{3}{*}{$\begin{array}{l}\text { Respondent } \\
\text { Code }\end{array}$} & \multicolumn{6}{|c|}{ Intervention group B } \\
\hline & \multicolumn{2}{|c|}{ Systolic } & \multicolumn{2}{|c|}{ Diastolic } & \multicolumn{2}{|c|}{ MAP } \\
\hline & Pre & Post & Pre & Post & Pre & Post \\
\hline 11 & 150 & 140 & 70 & 70 & 96.667 & 93.333 \\
\hline 12 & 160 & 150 & 80 & 70 & 106.67 & 96.667 \\
\hline 13 & 180 & 170 & 100 & 90 & 126.67 & 116.67 \\
\hline 14 & 180 & 170 & 90 & 80 & 120 & 110 \\
\hline 15 & 170 & 160 & 100 & 90 & 123.33 & 113.33 \\
\hline 16 & 170 & 160 & 90 & 80 & 116.67 & 106.67 \\
\hline 17 & 160 & 160 & 80 & 70 & 106.67 & 100 \\
\hline
\end{tabular}




\begin{tabular}{ccccccc}
18 & 150 & 150 & 80 & 70 & 103.33 & 96.667 \\
19 & 180 & 170 & 90 & 80 & 120 & 110 \\
20 & 150 & 140 & 70 & 70 & 96.667 & 93.333 \\
\hline Paired t-test & \multicolumn{2}{c}{$\mathrm{p} p=0,000$} & $\mathrm{p}=0,000$ \\
\hline
\end{tabular}

Table 4 The value of pre and post test, and the results of paired t-test intervention group C

\begin{tabular}{ccccccc}
\hline \multirow{2}{*}{$\begin{array}{c}\text { Respondent } \\
\text { Code }\end{array}$} & \multicolumn{7}{c}{ Intervention group C } \\
\cline { 2 - 7 } & Pre & Post & Pre & Post & Pre & Post \\
\cline { 2 - 7 } & 160 & 150 & 80 & 70 & 106.67 & 96.667 \\
21 & 180 & 170 & 100 & 90 & 126.67 & 116.67 \\
22 & 150 & 150 & 70 & 70 & 96.667 & 96.667 \\
23 & 180 & 170 & 90 & 80 & 120 & 110 \\
24 & 160 & 150 & 80 & 70 & 106.67 & 96.667 \\
25 & 170 & 160 & 90 & 80 & 116.67 & 106.67 \\
26 & 180 & 160 & 100 & 90 & 126.67 & 113.33 \\
27 & 170 & 160 & 90 & 80 & 116.67 & 106.67 \\
28 & 150 & 150 & 70 & 70 & 96.667 & 96.667 \\
29 & 150 & 140 & 80 & 70 & 103.33 & 93.333 \\
30 & \multicolumn{7}{c}{$\mathrm{p}=0,001$} & \multicolumn{2}{c}{$\mathrm{p}=0,000$} & & $\mathrm{p}=0,000$ \\
\hline
\end{tabular}

Table 5 The value of pre and post test, and the results of paired t-test control group

\begin{tabular}{ccccccc}
\hline \multirow{2}{*}{$\begin{array}{c}\text { Respondent } \\
\text { Code }\end{array}$} & \multicolumn{7}{c}{ Intervention group C } \\
\cline { 2 - 7 } & \multicolumn{2}{c}{ Systolic } & \multicolumn{2}{c}{ Diastolic } & \multicolumn{1}{c}{ MAP } \\
\cline { 2 - 7 } & Pre & Post & Pre & Post & Pre & Post \\
\hline 31 & 170 & 170 & 90 & 90 & 116.67 & 116,67 \\
32 & 150 & 150 & 70 & 80 & 96.667 & 103,33 \\
33 & 170 & 170 & 90 & 90 & 116.67 & 116,67 \\
34 & 180 & 180 & 100 & 100 & 126.67 & 126,67 \\
35 & 180 & 180 & 90 & 90 & 120 & 120 \\
36 & 150 & 160 & 80 & 70 & 103.33 & 100 \\
37 & 190 & 180 & 100 & 100 & 130 & 126,67 \\
38 & 170 & 170 & 90 & 90 & 116.67 & 116,67 \\
39 & 160 & 160 & 90 & 90 & 113.33 & 113,33 \\
40 & 160 & 160 & 80 & 80 & 106.67 & 106,67 \\
\hline
\end{tabular}

Table 6 Difference in mean blood pressure among groups with ANOVA test

\begin{tabular}{lcc}
\hline \multicolumn{1}{c}{ Group } & Average difference & P Value \\
\hline Systolic & 11 & 0,011 \\
Intervention group A & 8 & \\
Intervention group B & 9 & \\
Intervention group C & 0 & \\
Control group & & 0,014 \\
\hline Distolic & 10 & \\
Intervention group A & 8 & \\
Intervention group B & 8 & 0,011 \\
Intervention group C & 0 & \\
Control group & & \\
\hline MAP & 10,33 & \\
Intervention group A & 8,00 & \\
Intervention group B & 8,33 & \\
Intervention group C & 0 & \\
Control group & & \\
\hline Significant $\alpha \leq 0,05$ & &
\end{tabular}




\section{DISCUSSION}

From the results of the analysis showed that in the intervention group $A$ after being given the phaleria macrocarpa's fruit ethnic food complementary for 7 days, there is decrease of mean blood pressure values of both systolic, diastolic and MAP. This is proven by the paired t-test which results $p$ less than $\alpha$ $(\alpha \leq 0.05)$, that are $p=0,000$. In the intervention group B after being intervention for 7 days, there is a decrease of mean blood pressure values of both systolic, diastolic and MAP. This is proven by the paired t-test which results $p$ less than $\alpha(\alpha \leq 0.05)$, that are $p=0,000$. In the intervention group $C$ after being intervention for 7 days, there is a decrease of mean blood pressure values of both systolic, diastolic and MAP. This is proven by the paired t-test which results $p$ less than $\alpha(\alpha \leq 0.05)$, that is $p=0.001$ on systolic, and $p=0,000$ on diastolic and MAP. Whereas in the control group after being given ethnic food without mixed with phaleria macrocarpa, there isn't change in the mean blood pressure value of either systolic, diastolic or MAP. This is proven by the paired t-test which results $p$ more than $\alpha(\alpha \geq 0.05)$, that are $p=$ 1.000.

According to the study of Sudewa, Ismanto, \& Rompas (2014) which stated that there was an influence of the phaleria macrocarpa on decreasing blood pressure in patients with hypertension. Some chemicals contained in the fruit and leaves of the phaleria macrocarpa include alkaloids, flavonoids, polyphenols, and saponins (Maharani, 2016). Flavonoid compounds can reduce systemic vascular resistance (SVR) because it causes vasodilation and affects the work of angiotensin converting enzyme (ACE) which can inhibit the occurrence of changes in angiotensin I to angiotensin II. The effects of vasodilation and ACE inhibitors can reduce blood pressure (Junaedi, Yulianti, \& Rinata, 2013). Alkaloids function the same as drugs of $\beta$-blockers which have negative inotropic and negative chronotropic to the heart. The result is a decrease in cardiac output, decreased heart rate and lack of contraction strength of the myocardium. Peripheral resistance sometimes goes up, sometimes it also stays. Reduction of chronic cardiac output causes peripheral resistance to decrease. This causes a decrease in blood pressure (Apriyati, 2008 in Mantong, 2017).

$$
\text { According to Mantong (2017), }
$$

Saponins have diuretic effect by reducing plasma volume and removing water and electrolytes, especially sodium, so that ultimately cardiac output decreases. According to the table 6 , showed the mean difference of 4 groups. The intervention group A or giving phaleria macrocarpa's fruit ethnic food complementary is the most effective compared to other groups with $p$ value $=0.011$ on systolic, $p$ value $=0.014$ on diatolic, and $p$ value $=0.011$ on MAP. All respondents in Group A (100\%) have a decrease in systolic blood pressure with mean difference of $11 \mathrm{mmHg}$. Almost all respondents A (90\%) have a decrease in diastolic blood pressure with mean difference of $10 \mathrm{mmHg}$. All respondents of group A (100\%) have a decrease in MAP with mean difference of $10.33 \mathrm{mmHg}$. The direct effect of reducing blood pressure can be seen 1 hour after intervention of phaleria macrocarpa ethnic food complementary. This is accord with the study of Daud, Badruzzaman, Sidik, \& Tawang (2016) which states that methanol fruit extract Phaleria macrocarpa shows anti-hypertensive activity. In addition, the study of Sudewa et al. (2014) and Baradero, Dayrit, \& Siswadi (2008) stated that the results of statistical tests of blood pressure measurements before and after being given therapy for phaleria macrocarpa fruit decoction in the intervention group obtained a significance of 0,000 . The direct effect of the decline can be seen 1 hour after giving the god crown fruit. The magnitude of the decrease in blood pressure during the intervention of the phaleria macrocarpa's fruit varies, depending on the response of each respondent (Sudewa et al., 2014). According to research by Soeksmanto, Hapsari, \& Simanjuntak (2007), based on the results of analysis of antioxidant testing of the phaleria macrocarpa, the inhibition value in 100 ppm ethanol extract on the phaleria macrocarpa's old fruit is $83.08 \%$ and inhibition value in $100 \mathrm{ppm}$ methanol extract on the phaleria macrocarpa's old fruit is $79.03 \%$. While the inhibition value in $100 \mathrm{ppm}$ ethanol extract on the phaleria macrocarpa's leaves is $43.69 \%$ and the inhibition value in $100 \mathrm{ppm}$ methanol extract on the phaleria macrocarpa's leaves is $38.46 \%$. This shows that the inhibition power of the phaleria macrocarpa's fruit is higher than the leaves caused by the composition of fruit flavonoids is higher than the leaves.

Respondents in code R8 had the highest rate of reduction in systolic and diastolic pressure, which is $20 \mathrm{mmHg}$ after being given 
phaleria macrocarpa's fruit for 7 days. This happened because the $\mathrm{R} 8$ respondents were the youngest respondents in the group and were routinely involved in physical activity. In addition, respondent in code R37 also had the highest reduction in systolic pressure in the intervention group C, which is $20 \mathrm{mmHg}$. Although the respondent R37 were not the youngest in the group, but she is routine in carrying out physical activities. Whereas in respondents $\mathrm{R} 17, \mathrm{R} 18, \mathrm{R} 23$, and $\mathrm{R} 29$ there was no change in blood pressure after 7 days given the phaleria macrocarpa ethnic food complementary. The reason is because the respondents included the oldest age, not routine of physical activity, and not routine or did not take antihypertensive drugs. According to the functional consequence theory developed by Miller (2012), the quality of life of elderly people is affected by changes related to age and risk factors. As age increases, physical and functional changes are inevitable, progressively over time and irreversible. While risk factors include lifestyle, support systems, environment, psychosocial conditions, and attitudes based on lack of knowledge. This combination can cause negative functional consequences.

Negative functional consequences are all forms of disorders that affect the quality of life of the elderly. The role of nurses in this case aims to improve the welfare of the elderly by considering two components, namely changes related to age and risk factors (Miller, 2012). One form of this intervention is complementary therapy. The complementary therapy carried out in this study is the phaleria macrocarpa ethnic food complementary which can reduce blood pressure, so that it can change negative functional consequences into positive functional consequences.

\section{CONCLUSION}

All respondents in the treatment group A experienced a decrease in systolic blood pressure. Almost all respondents in the treatment groups $\mathrm{B}$ and $\mathrm{C}$ experienced a decrease in systolic blood pressure. Almost all control group respondents did not experience changes in systolic blood pressure

All respondents in the treatment group A experienced a decrease in diastolic blood pressure. Almost all respondents in the $B$ and $\mathrm{C}$ treatment groups experienced a decrease in diastolic blood pressure. Almost all control group respondents did not experience changes in diastolic blood pressure.
All treatment group $A$ and $C$ respondents experienced a decrease in MAP. Almost all respondents in the treatment group B experienced a decrease in MAP. Almost all control group respondents did not experience changes in systolic blood pressure. The administration of herbal crown god getuk intervention has an effect on the decrease in blood pressure in elderly hypertension. UPT PSTW Blitar is expected to be able to create a work program to increase efforts to treat hypertension in the elderly with complementary or alternative efforts. In the management of hypertension, phaleria macrocarpa ethnic food complementary can be used as a pharmacological companion therapy for the elderly with hypertension.

\section{REFERENCES}

Abdullah, M. (2005). Faktor yang Berhubungan dengan Kejadian Hipertensi pada Kelompok Usia Lanjut di kecamatan Pegandon Kabupaten Kendal. Universitas Diponegoro.

Altaf, R., Umar, M. I., Asmawi, M. Z., Sadikun, A., Dewa, A., Manshor, N. M., ... Khadeer,

M. (2018). Polar components of Phaleria macrocarpa fruit exert antihypertensive and vasorelaxant effects by inhibiting arterial tone and extracellular calcium influx, 14(56), 312-327.

Andriadi, D. (2016). Pengaruh mahkota dewa terhadap tekanan darah usia lanjut dengan hipertensi di Dusun Biru Trihanggo Gamping Sleman Yogyakarta. Universitas 'Aisyiyah Yogyakarta.

Baradero, M., Dayrit, M. W., \& Siswadi, Y. (2008). Seri Asuhan Keperawatan Klien Gangguan Kardiovaskular. Jakarta: EGC.

Daud, D., Badruzzaman, N. A., Sidik, N. J., \& Tawang, A. (2016). Phaleria macrocarpa Fruits Methanolic Extract Reduces Blood Pressure and Blood Glucose in Spontaneous Hypertensive Rats ( SHR ), 6(01), 158-161. https://doi.org/10.7324/JAPS.2016.60 0126.

Dinkes Kabupaten Tulungagung. (2017). Profil Kesehatan Kabupaten Tulungagung 2016. Tulungagung.

Dinkes Provinsi Jatim. (2013). Riset Kesehatan Dasar dalam Angka (Riskesdas 2013) Provinsi Jawa Timur. (H. Susilowati, M. Sudomo, \& 
A. Suprapto, Eds.). Jakarta: Tim Riskesdas 2013.

Efendi, F., \& Makhfudli. (2009). Keperawatan Kesehatan Komunitas; Teori dan Praktik dalam Keperawatan. (Nursalam, Ed.). Jakarta: Salemba Medika

James, P. A., \& Ortiz, E. (2014). JNC 8 Hypertension Guideline Algorithm, 311(5). Januariani. (2018). Tulungagung dalam Rasa (1st ed.). Yogyakarta: Deepublish.

Junaedi, E., Yulianti, S., \& Rinata, M. G. (2013). Hipertensi Kandas Berkat Herbal. (T. Yulia, Ed.). Jakarta Selatan: FMedia (Imprint AgroMedia Pustaka).

Kemenkes RI. (2013). Riset Kesehatan Dasar; RISKESDAS 2013. Jakarta: Badan Penelitian dan Pengembangan Kesehatan.

Kemenkes RI. (2014). Pusat Data dan Informasi Kementerian Kesehatan RI; Hipertensi.

Jakarta Selatan: Pusat Data dan Informasi Kemenkes RI.

Kusmardi, K., Tamzir, A. R., Widiasari, S., \& Estuningtyas, A. R. I. (2018). Suppression Effect Of Mahkota Dewa ( Phaleria Macrocarpa) Leaf Extract in Chitosan Nanoparticles on The Small Intestine of Dextran Sulfate SodiumInduced Mice: Focus on Mitosis and Hyperplasia, 11(6), 11-13.

Lilly, T. E. (2015). 25 Kreasi Antaran Cantik dari Getuk Singkong. Jakarta: Gramedia. Mantong, Y. A. (2017). Pengaruh Pemberian Air Rebusan Daun Alpukat terhaap Penurunan Tekanan Darah Pasien Hipertensi Laki-Laki. Universitas Hasanuddin Makassar.

Martin, J. (2008). Hypertension Guidelines: Revisiting the JNC 7 Recommendations. The Journal of Lancaster GeneralHospital, 3(3), 91-97. https://doi.org/10.1001/jama.290.10.1 $312-c$
Miller, C. A. (2012). Nursing Care of Older Adults: Theory and Practice Second Edition. Philadelphia: Lippincolt Company.

Noorhidayah, S. A. (2016). Hubungan Kepatuhan Minum Obat Antihipertensi terhadap Tekanan Darah Pasien Hipertensi di Desa Salamrejo. Universitas Muhammadiyah Yogyakarta.

Nursalam. (2016). Metodologi Penelitian IImu Keperawatan (4th ed.). Jakarta: Salemba Medika.

Padila. (2013). Keperawatan Gerontik (Pertama). Yogyakarta: Nuha Medika.

Priharninuk, D. (2017). Efek Stimulus Konstektual (Mie Herbal Mhkota Dewa dan Aroma Terapu Lavender) terhadap Penurunan Tekanan Darah dan Peningkatan Ankle Brachial Indeks pada Lansia dengan Hipertensi di Jombang. Universitas Airlangga.

Soeksmanto, A., Hapsari, Y., \& Simanjuntak, P. (2007). Kandungan Antioksidan pada Beberapa Bagian Tanaman Mahkota Dewa, Phaleria macrocarpa (Scheff) Boerl. (Thymelaceae), 8, 9295.

Sudewa, I. W. B., Ismanto, A. Y., \& Rompas, S. (2014). Pengaruh buah mahkota dewa (phaleria macrocarpa) terhadap penurunan tekanan darah pada Penderita hipertensi di Desa Werdhi Agung Kecamatan Dumoga Tengah Kabupaten Bolaang Mongondow. Universitas Sam Ratulangi Manado.

Widyatuti. (2008). Terapi Komplementer dalam Keperawatan. Keperawatan Indonesia, 12(1), 53-57.

Yuliana, C. D. (2017). Pengaruh JAKI-MAAP (Jalan Kaki, Markisa, dan Air Putih) terhadap Perubahan Kolesterol dan Tekanan Darah pada Lansia Hipertensi. Universitas Airlangga 